\title{
One hundred years of epilepsy surgery: Sir Victor Horsley's contribution
}

\author{
DAVID C TAYLOR
}

From the Royal Manchester Children's Hospital, Manchester, UK

"If you can meet with Triumph and Disaster

And treat those two impostors just the same"

(Kipling, "If", 1910)

On May 25th, 1886, Victor Horsley, then aged 29 years, another brilliant recent recruit to the burgeoning National Hospital for the Paralysed and Epileptic in Queen Square, performed his first brain operation on a patient. ${ }^{2}$ There was no tradition of neurological surgery, so there could be no apprenticeship, and although Macewen in Glasgow (1879), ${ }^{3}$ Rickman Godlee in London (1884) and Durante in Italy (1884), had operated on the brain, their operations passed largely unnoticed. Horsley's facilities, in a converted day-room off a ward, were primitive but his personal preparation was extensive. He had already engaged upon a very large amount of experimental brain surgery on animals from which he derived experience which could be wedded to his extraordinary dexterity, technique, and an astounding knowledge of the kind of anaesthesia required. Horsley was also a man given to zealous crusades and one of his crusades was about antisepsis. His techniques of sealing the bone edge with antiseptic wax, ${ }^{4}$ and turning a comma-shaped flap instead of the old cruciform incision, both assisted in the control of infection. Moreover, his characteristic optimism was reinforced by remarkable luck.

His first patient, James B, then aged 22 years, suffered epilepsy from the age of 15 following a severe head injury received in a road traffic accident at the age of seven. ${ }^{5}$ At that age he had been in the Edinburgh Royal Infirmary with a depressed comminuted fracture. Debridement was performed but the wound suppurated and the brain herniated. His hemiplegia cleared after seven weeks. In 1886 he was

Address for reprint requests: David C Taylor, Jesson House (Royal Manchester Children's Hospital), Manchester Road, Swinton, Manchester M27 IFG, UK.

Received 18 November 1985. Accepted 23 November 1985 suffering prolonged episodes of "Jacksonian" status epilepticus. Thus the origin of his attacks was obvious and the location of his cortical scar was very apparent. It proved to be highly vascular, measuring 3 by $2 \mathrm{~cm}$. It was removed with half a centimetre of surrounding brain substance. Horsley was not keen on drainage but initially made brief use of drainage tubes. ${ }^{6}$ The wound healed, the post-operative motor and sensory losses faded. There were no more fits.

Hughlings Jackson, whose patient James B was, was in theatre with David Ferrier to witness Horsley's feat; being a somewhat whimsical man, he remarked to Ferrier that Horsley had missed a chance to put a joke into a Scotsman's head!? Soon afterwards, while watching Horsley and Beevor performing stimulation experiments on a monkey's brain, he observed that the animal's motor responses to stimulation were identical to those suffered by one of his patients in his seizures. Thus Thomas W, with a personal and family history of tuberculosis, became Horsley's second patient. The lesion was where Jackson predicted it would be, and indeed it proved to be a tuberculoma. He survived for another eight years. The third patient, George W, under Dr Buzzard, was another traumatic epileptic. He had suffered a variety of head traumata from the tender age of 5 years in his occupation as a stable help. (This is an interesting sidelight on those harsh times). There was extreme local tenderness over an old depressed fracture near the midline in the left parietal bone. Horsley argued that the symptoms, particularly the rectal aura, confirmed the location of the lesion from other experiments that he had made with Schäfer. He turned a flap and made a wide debridement of the area which had been lacerated by fragments of the inner table. This was a further success. In a brief aside in his 1909 paper he remarks that this patient is in "robust good health".

He had been appointed to Queen Square only in the February of 1886, started operating in May, and presented his results, and his first three patients in person to the Annual Meeting of the British Medical Association in August. His presentation made a tremendous impact. Charcot, who had been one of his 
referees for the Queen Square post, was in the audience as were Jackson and an admiring Professor EP Thuring from Brooklyn, who had witnessed the third operation. Horsley's friends, Frank Cutlack and CJ Bond, each describe his "glorious triumph" and his need to walk off the heady sensations induced by the great reception given to his paper. ${ }^{9}$ The year 1886 was his annus mirabilis. Apart from these clinical achievements, he became a founder member of the Neurological Society of London, he was placed on a Committee of the Local Government Board which was inquiring into Pasteur's method of dealing with rabies, which launched another of his major achievements, and he was elected a Fellow of the Royal Society. He was henceforth a major and commanding figure in the medical establishment. Within a year he had performed eleven operations on the brain and established himself sufficiently well financially to marry in 1887 his fiancee of some four years, Eldred Bramwell.

He was the third born of seven children of John Calcott Horsley, an established and successful painter, a Royal Academician, who, inter alia, painted the altar painting in St Thomas' Hospital Chapel, "The Healing Mercies of Christ". His mother, Rosamund Haden, was the daughter and also the sister of a physician. Through her connection with a lady-in-waiting of Queen Victoria, whose daughter Beatrice was also born on 14th April 1857, the Queen indicated that the boy might have her names in the form Victor Alexander. Their London home was at what is now known as 128 Church Street, Kensington. This splendid house still stands. Dating originally from about 1736 , it was enlarged in $1842{ }^{10} \mathrm{~A}$ former resident had been Muzio Clementi and Victor's grandfather, not only a composer but also an organist. Felix Mendelssohn had been a visitor to the house and his "Midsummer Night's Dream" was said to have been first played there. John Horsley preferred, however, to bring up the family in the country at Willesley, ${ }^{11}$ near Cranbrook in Kent where he established a colony of artists, perhaps because his first wife died of tuberculosis and all three of their children died of scarlet fever. He gave his first-born son by his second marriage his first wife's surname, Walter. In the event, two of the seven children born to the marriage also died of scarlet fever. Gerald Horsley, who became an architect, died in 1917. His two sisters both married distinguished physicians. Victor Horsley shared with his brother Gerald the traits of a white forelock and some colour blindness, but he was, in addition, perfectly ambidextrous.

Although his contemporary biographers seem to see his background as average for a nice middle-class lad, there were certain privileges and influences which were highly germane to his later career. His mother was brought up in France and Victor would communicate with her in French, a factor which might have had some influence on his relationship with Charcot and Pasteur. He also had a German governess and as a student he had made several extended trips in that country. He thus had ready access to important European medical publications. Then there was the family tradition of devotion to causes. His father campaigned, to the point of being ridiculed, against the use of nude models by artists. His uncle, Sir Seymour Haden, both an artist and physician, was a campaigner against cremation. He favoured burial, "earth to earth" and invented a papier maché coffin to facilitate it. Victor Horsley's energy was always prodigious, his country walks would cover 20 miles in vile conditions or extend to $\mathbf{4 0}$ miles on a better day. Having exhausted all his friends on a mountain climb, he spent the rest period on the peak collecting and burying the rubbish. He had a life-long preoccupation with military matters, especially shooting and drill. He hoped for a career as a cavalry officer, but responded to the suggestion of medicine by saying, "Oh! All right, plenty of riding and driving and cutting about." Nevertheless, he joined the Artists' Rifles as a student, went regularly to camp and eventually thrust himself forward for military service in 1914 at the age of 57 years.

Before entering University College Hospital in October 1875, he was tutored privately. He lived at home in Kensington, worked assiduously but found that alcohol impaired his capacity to do so, and became a life-long campaigning teetotaller. He took a similar stand against tobacco. His hard work and his brilliance were rewarded with prizes, scholarships and the better jobs. He was a pupil of Marcus Beck, Lister's cousin and disciple, from whom he learned antisepsis, and of William Gowers, twelve years his senior. He made two illustrations for Charlton Bastian's book. In the MB, BCh finals in 1881, he was the University Prizeman in Surgery. The range of his characteristics and interests was partly encompassed by his nicknames, which were Archibald Allright (optimism), The Germ (Bacteriology and Antisepsis), The Professor (his general knowledge) and The Vulture (operating on corpses and doing necropsies).

After a break in Germany, he became Surgical Registrar at University College Hospital in 1882 and was valued by Schäfer for his brilliant surgery on animals being used for experimental physiology. By 1884 he was in charge of the Brown Institution, one of the few research institutions available for animal research. His experimental thyroid surgery proved the connections between thyroid deficiency and myxoedema, cachexia strumpriva, and cretinism and the capacity for replacement gland to correct it. ${ }^{12} \mathrm{He}$ became FRCS in 1883 and was elected to the staff of Univer- 
sity College Hospital in 1885, where in 1893 he became Professor of Pathology. By $1890^{13}$ he had performed 44 operations on the CNS including 19 on the spinal cord where in his first dramatic foray in 1887 on a patient of Gowers, he removed what by good luck proved to be a pedunculated intradural extramedullary tumour! The skill of his operation astounded Osler. ${ }^{14}$

He founded the Journal of Pathology in 1891, was given the Gold Medal of the Royal Society in 1894, he was knighted in 1902.

Of his 100 or so publications, 50 were published by 1890 and his scientific work fell off dramatically from 1900 on. "What can have been the pressures or possibly the ambitions that made a man already internationally famous retire from one of London's premier teaching hospitals when he was 49?" (Jefferson $1957^{16}$ ). He had been largely responsible for the policy which eliminated rabies in the UK by forcing through Pasteur's advice; he launched the surgery of tic douleureux. His 1886 paper $^{5}$ records his first three and the 1887 paper $^{6}$ reports his first ten brain operations. But beyond the $1890^{13}$ report there is absolutely no systematic mention of the outcome of surgery for epilepsy. Nor did he, or his contemporaries with the exception of WW Keen, or his subsequent biographers, grasp the importance of this "epilepsy surgery", as opposed to his surgery of cerebral tumours. ${ }^{1718} \mathrm{He}$ nearly understood. "In conclusion I think the details of the cases contained in the accompanying table show that the operation of exposing and removing considerable quantity of brain is not to be ranked among the 'dangerous procedures' of surgery". 6 He hated writing scientific papers, he did it rather badly, as Jefferson remarked, ".... the published report is maddeningly brief". Even then he acknowledges his debt to his research assistant, a Dr Wilson, the house physician at Queen Square, for both the 1886 and 1887 papers.

Why would this remarkable, puritanical, honest, plain-speaking surgeon withdraw so totally from the very arena that had proved his preeminence?

At the time of their marriage the Horsleys lived at 80 Park Street, off Grosvenor Square, but later they removed to 25 Cavendish Square, a property previously owned by Dr CB Radcliffe and before him by Brown-Séquard. They had three children, Siward, Oswald and Pamela. Horsley was devoted to the family and was capable of working while family life went on around him, though his prose may have suffered somewhat by their distractions. His biographer, JB Lyons, ${ }^{2}$ recounts that, in his late teens, at a concert in the Albert Hall, Siward suddenly became unconscious and convulsed. Epilepsy was diagnosed and an operation was suggested. Only Sir Victor himself was regarded as appropriately competent and it was on him that the awful responsibility fell. Although there was sufficient recovery after surgery for Siward to join the army and gain a commission in 1914, he was invalided out and did factory service in Manchester. After the war he returned to his school, Bedales, as a master but died within a few years.

Lyons writes: "From the world at large he (Sir Victor) concealed his embitterment but to his family the shadow of frustration and disappointment was evident." A contemporary describes him: "I remember seeing him at one of these meetings: thin, palefaced, restless, with tousled hair and the eyes of a fanatic. Carelessly dressed, he was totally unlike the picture one visualises of the bland polished man of the world associated in the mind of the public with the name of a Harley Street consultant."

I wonder whether Siward's first fit did actually chance to be public or whether the onset of his epilepsy might have coincided with Sir Victor's remarkable change in outlook and output from 1900 on.

When in 1957 to celebrate the 100th anniversary of his birth, Jefferson ${ }^{16}$ came to write on "the man", he wrote: "But to speak of a personality from hearsay is dangerous and almost impertinent". This rather restrains speculative psychopathography but we are nevertheless the heirs of traditions, of belief systems, of attitudes and methods. It is better to know something of their history and their origins, and, as they are the products of men, to try to understand those men. Horsley was a giant, a polymath of enormous energy and zeal. Just as he threw himself into his studentship, his research and his several major clinical projects, so later he hurled himself into rescuing the Medical Defence Union, reforming the General Medical Council, ${ }^{19}$ reorganising and liberalising the British Medical Association, defending the members of the Royal College of Surgeons against the autocracy of the Fellows, supporting Lloyd George's Insurance Bill (the grandfather of our National Health Service) against the greedy conservatism of doctors, demanding equality for women in medicine, seeking proper recognition of the profession of nursing, and helping to obtain Votes for Women (the Suffragette Movement). Everywhere his blunt and savage style won him friends, but also enemies in equal or greater number. "What demon" wrote Osler (1916) $)^{14}$ "drove a man of this type into the muddy pool of politics?" And his able pupil, Wilfred Trotter (1916) ${ }^{20}$ said of him, "He occupied so prominent a place in regard to controversies of many and widely different kinds, that perhaps no man was more generally discussed and criticised than he by different groups of men...".

He died in Amara, on the Tigris in Mesopotamia on 16th July 1916 of so-called heat stroke. He was 59 , he was still in the habit of setting himself grossly exhausting schedules. His military obituarist wrote: "It 
was unwise for a man of his age, who had had no experience of tropical heat, usages, or habits, to have gone to work in the confines of the Persian Gulf. He should not have been there. His life has been thrown away." (Sir Havelock Charles, 1916). ${ }^{21}$ Another military colleague wrote: "How he came to volunteer for Mesopotamia is characteristic of him. He had come through a period of intense family anxiety when he met at dinner one evening in February a man who related stories of the horrors of the Tigris campaign... So he volunteered without consulting his friends or relatives..." (McCarrison, 1916). ${ }^{22}$

No elegant blue plaque on a house in London celebrates his memory as one does for Hughlings Jackson. Perhaps a certain obloquy remains; he might have been seen by important contemporaries as a bigot but more likely they feared his socialism. He just failed to be elected to Parliament, ${ }^{23}$ as he just failed to be President of the BMA, or make it to the House of Lords.

His prodigious energy, his brilliant intelligence, his rigorous self-denial, his astonishing memory, must have made him a formidable adversary. Yet from the biographical material he shines through as an admirable man.

"What demon?", Osler asked. ${ }^{14}$ Was it Siward's? How could he have borne to be visited, through his own son, with what he had laboured so fiercely to conquer in his patients?

This paper was first given as a lecture at an International Meeting on Epilepsy Surgery, held at Palm Springs on February 20th-23rd, 1986, the proceedings of which are to be published by Raven Press. I am grateful to Mrs Jean Tandy for her helpful persistence in obtaining the biographical material, the references, and for her careful assistance with the manuscript.
References

${ }^{1}$ Kipling R. Rewards and Fairies. London: McMillan, 1910.

${ }^{2}$ Lyons JB. The Citizen Surgeon. London: Peter Dawnay Ltd, 1966.

${ }^{3}$ Duguid C. Macewen of Glasgow. Edinburgh: Oliver \& Boyd, 1957.

${ }^{4}$ Wilkins RH. Neurosurgical Classics-XXI. J Neurol 1964;21:713-4.

${ }^{5}$ Horsley V. Brain-Surgery. $\mathrm{Br} \mathrm{Med} J$ 1886;2:670-5.

${ }^{6}$ Horsley V. Remarks on ten consecutive cases of operations upon the brain and cranial cavity to illustrate the details and safety of the method employed. $\mathrm{Br} \mathrm{Med} \mathrm{J}$ 1887;1:863-5.

${ }^{7}$ Paget S. Sir Victor Horsley. London: Constable \& Co Ltd, 1919.

${ }^{8}$ Horsley V. The Linacre Lecture on The Function of the So-Called Motor Area of the Brain. Br Med J 1909;2:125-32.

${ }^{9}$ Bond CJ. Recollections of Student Life and Later Days. London: HK Lewis \& Co Ltd, 1939.

${ }^{10}$ Greater London Council. Survey of London, Vol XXXVII. London: Athlone Press, 1972:38-40.

${ }^{11}$ The Cranbrookian. Sir Victor Horsley. The Cranbrookian, 1916:72-3.

${ }^{12}$ MacNulty Sir A. Sir Victor Horsley: His Life and Work. Br Med J 1957;1:910-6.

${ }^{13}$ Horsley V. Remarks on the surgery of the central nervous system. Br Med J 1890;2:1365-8.

${ }^{14}$ Osler Sir W. In: Obituary. Br Med J 1916;2:165.

${ }^{15}$ National Institute of Neurological Diseases and Blindness/National Institutes of Health. Great Names in Neurology. US Department of Health, Education and Welfare, 1957:25-38.

${ }^{16}$ Jefferson Sir G. Sir Victor Horsley, 1857-1916: Centenary Lecture. Br Med J 1957;1:903-10.

${ }^{17}$ Horsley V. Discussion on the Treatment of Cerebral Tumours. Br Med J 1893;2:1365-8.

${ }^{18}$ Horsley V. Address in Surgery on The Technique of Operations on the Central Nervous System. Lancet 1906;2:484-90.

${ }^{19}$ Horsley V. Abstract of an Address on The Work of the General Medical Council. Lancet 1898;2:1692-5.

${ }^{20}$ Trotter W. In: Obituary. Br Med J 1916;2:162-3.

${ }^{21}$ Charles Sir RH. In: Obituary. Br Med J 1916;2:165.

${ }^{22}$ McCarrison Maj R. In: Obituary. Br Med J 1916;2:166.

${ }^{23}$ Cox Dr A. In: Obituary. Br Med J 1916;2:164-5. 